九州大学学術情報リポジトリ

Kyushu University Institutional Repository

Karyotypes of the Japanese Harvest Mouse (Micromys minutus japonicus) from Fukuoka and the Tsushima Islands

Okura, Nobuhiko

Zoological Laboratory, Faculty of Agriculture, Kyushu University

Shiraishi, Satoshi

Zoological Laboratory, Faculty of Agriculture, Kyushu University

Uchida, Teruaki

Zoological Laboratory, Faculty of Agriculture, Kyushu University

https://doi.org/10.5109/23787

出版情報: 九州大学大学院農学研究院紀要. 28 (4)，pp. 177-183，1984-03. Kyushu University バージョン：

権利関係 : 


\title{
Karyotypes of the Japanese Harvest Mouse (Micromys minutus japonicus) from Fukuoka and the Tsushima Islands*
}

\author{
Nobuhiko Okura ${ }^{\dagger}$, Satoshi Shiraishi and Teru Aki Uchida \\ Zoological Laboratory, Faculty of Agriculture, \\ Kyushu University 46-06, Fukuoka 812 \\ (Received November 29, 1983)
}

\begin{abstract}
Karyotypes of the Japanese harvest mouse, Micromysminutus japonicus, from two populations occurring in Fukuoka and the Tsushima Islands, were examined in detail using conventional, G- and C-band stainings. There was no difference in karyotype both between the two populations and within each population. The karyotypes in the two populations concerned were much the same as in other Japanese and Eurasian populations. Thus, it may be said that the harvest mouse has a quite conservative karyotype in spite of its wide geographical distribution. So far as it is based upon the karyotype, this conservatism does not support a specific division of the Japanese harvest mouse (M. japonicus) from the Eurasian o ne (M. minutus), which was proposed by Tokuda (1941), thus we regard the Japanese harvest mouse as $M$. minutus; moreover, $M$. minutus aokii (Kuroda, 1922) from Tsushima seems to be a synonym of $M$. minutus japonicus (Thomas, 1905) from the mainland of Kyushu.
\end{abstract}

\section{INTRODUCTION}

Genus Micromys, the harvest mouse, is one of the smallest rodents, distributing widely from the Far East to Europe. According to the classification of Palaearctic mammals (Corbet, 1978), the genus consists of the single species (M.minutus) divided into 9 subspecies, However, the taxonomy of the harvest mouse has not been studied thoroughly because of its wide-spread distribution and a scanty knowledge of geographical variation. The classification of the Japanese harvest mouse also has not yet been completed (Aimi and Kaneko, 1971; Imaizumi, 1979 ; Murakami, 1981).

Recently, advances in the systematics of mammals have been establishing by karyotype analysis. Especially, cytogenetical data have made a great contribution to the systematics of Japanese rodents such as black rats (Yosi$\mathrm{da}, 1980$ ) and wood mice (Tsuchiya, 1974). The Japanese harvest mouse, however, has been karyotyped by only conventional staining (Tsuchiya and Yosida, 1971; Tsuchiya, 1979, 1981), but not yet by other banding techniques.

The present paper deals with the karyotype analysis of the Japanese harvest mouse from two populations inhabiting Fukuoka (the mainland of

* Reprint requests to Dr. S. Shiraishi.

+ Present address: Department of Anatomy, School of Medicine, University of the Ryukyus, Nishihara, Okinawa 903-01 
Kyushu) and the Tsushima Islands by conventional, G- and C-banding procedures. Further, the classification of the Japanese harvest mouse is discussed on the basis of the karyotype.

\section{MATERIALS AND METHODS}

Seven specimens $(4 \pi, 3$ 우) captured with live-traps in Hisayama-machi near Fukuoka City and five $(3 \precsim \diamond, 2$ 우 $)$ from the Tsushima Islands, Nagasaki Prefecture were used. The conventional staining was performed by the bone marrow air-drying method (Yosida, 1980), G-band was stained in accordance with the method by Seabright (1971) and C-band by Sumner (1972). In conformity with John (1976), the chromosomes were morphologically grouped as metacentrics (M, long arm length/short a. $1 .=1 \sim 2.5)$, acrocentrics (A, 3-10) and telocentrics $(\mathrm{T}, \infty)$, subsequently arranged in order of size.

\section{RESULTS}

\section{Conventional karyotype (Fig. 1)}

There was no difference in karyotype between the Fukuoka and Tsushima populations, all specimens having the same karyotype. The karyotype consisted of one large metacentric pair (M-l), 4 small metacentric pairs (M-25), 28 acrocentric pairs ranging from large to small (A-1-28), a large-sized acrocentric $\mathrm{X}$ - and a small acrocentric Y-chromosome $(2 \mathrm{n}=68)$. The Xchromosome possessed $5.5 \%$ of the female haploid set on the average of 58 cells observed.

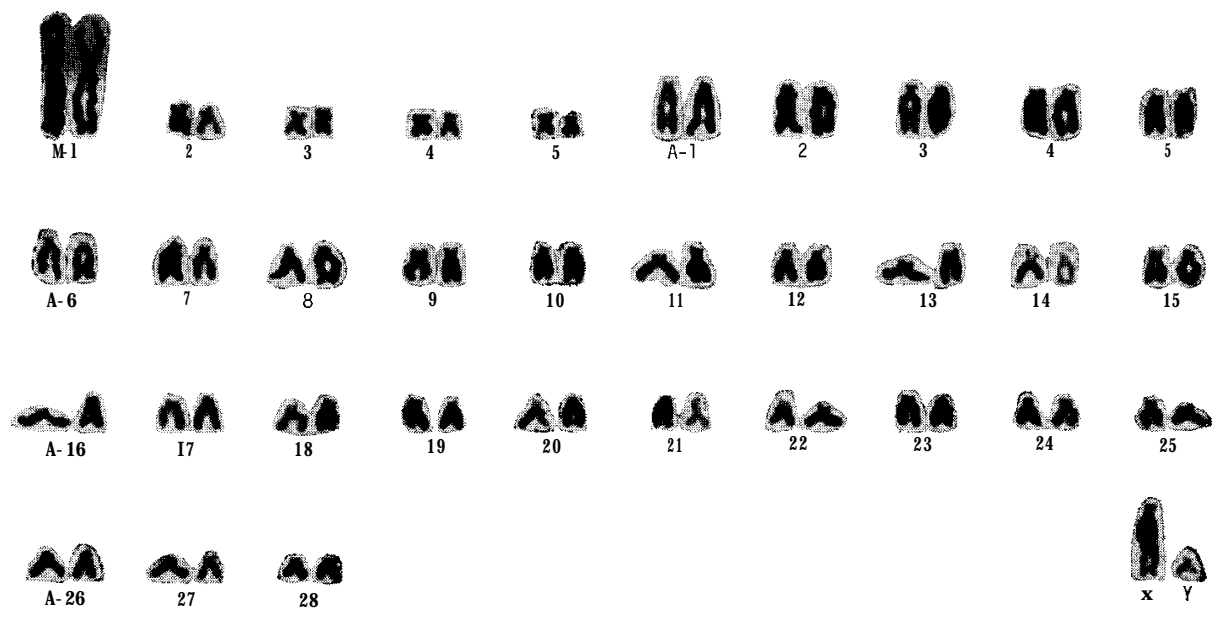

Fig. 1. Conventional karyotype of the Japanese harvest mouse from Fukuoka. x 2,000. 
2. G-banding pattern (Fig. 2)

All specimens of the two populations showed the same G-banding pattern. The centromeric regions of the autosomes except M-2-5 and the sex chromosomes were G-band positive.
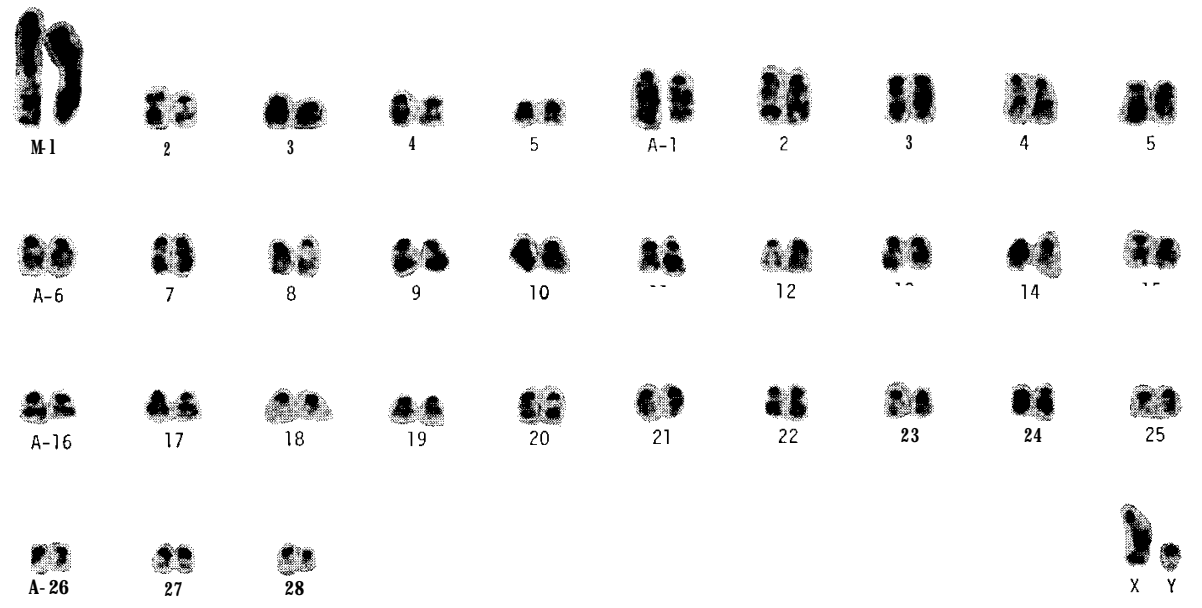

Fig. 2. G-band karyotype of the Japanese harvest mouse from Fukuoka. x 2,000 .

\section{C-banding pattern (Fig. 3)}

There was no difference in C-banding pattern both between the two populations and within each population, as far as we examined. Although M-l had no C-band material, the other autosomes and sex chromosomes possessed

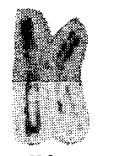

MI
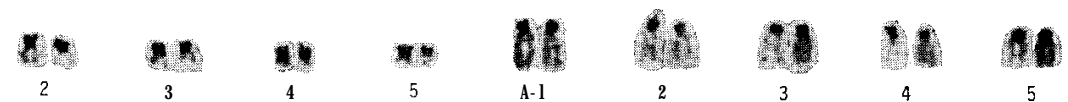

\section{in is}
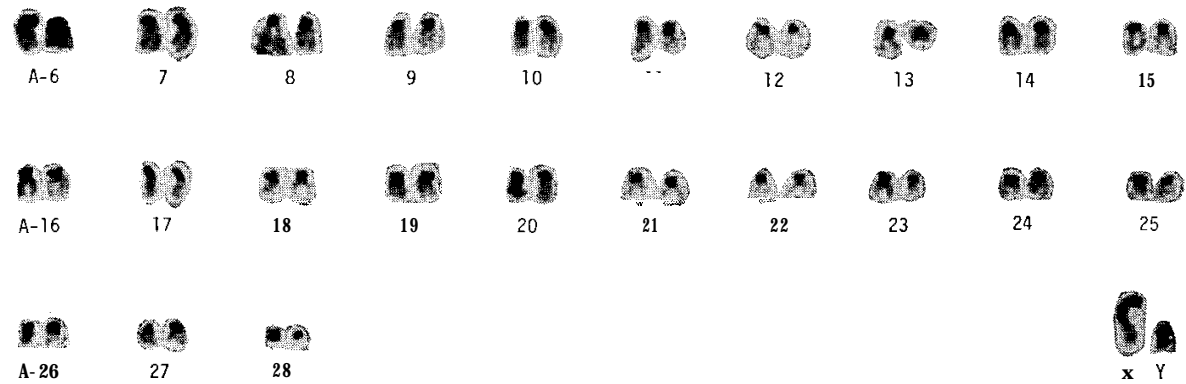

Fig 3. C-band karyotype of the Japanese harvest mouse from the Tsushima Islands. $\sim 2,000$. 
centromeric C-band material. The autosomes except $\mathrm{M}-\mathrm{I}$ and the X-chromosome had heterochromatic short arms, and the $\mathrm{Y}$-chromosome was totally $\mathrm{C}$ band positive.

\section{DISCUSSION}

The conventional karyotype of the harvest mouse from the two Japanese populations was the same as that of this mouse from other Japanese (Tsuchiya and Yosida, 1971; Tsuchiya, 1979, 1981), western Siberian and Czechoslovakian (Král, 1971, 1972) populations. Moreover, the G- and C-banding patterns of this mouse were in good agreement with those of the western German harvest mouse (Jiides, 1981) ; however, individual variations in amount of centromeric C-band material, which were suggested by him, could not be recognized in any of the 12 specimens of the two Japanese populations. The similarity in conventional karyotype and/or in C-banding pattern among the Fukuoka, Tsushima, other Japanese and Eurasian populations suggests that the karyotype of the harvest mouse is quite conservative in spite of its wide-spread distribution.

As for the classification of the Japanese harvest mouse, firstly this mouse inhabiting Shikoku and Kyushu was divided from M. mimutus minutus occurring in Eurasia as a subspecies, M. minutus japonicus (Thomas, 1905), subsequently these mice from the Tsushima Islands and Honshu were taken the name of M. minutus aokii (Kuroda, 1922) and M. minutus hondonis (Kuroda, 1933), respectively. On the other hand, Tokuda (1941) separated the Japanese harvest mouse from $M$. minutus as a different species, $M$. japonicus, including the above three subspecies. Imaizumi (1949, 1970), however, has not agreed with Tokuda's opinion. Although the most prominent character in the classification of these three Japanese subspecies was said to reside in a difference of the tail coefficient, it has now been regarded as an insignificant character (Shiraishi, 1964; Imaizumi, 1970; Kaneko, 1974). In this connection, Imaizumi et al. (1980) proposed that $M$. minutus hondonis is a synonym of $M$. minutus japonicus. Thus, the classification of the Japanese harvest mouse has been confused at both species and subspecies level.

The rate of karyotypic evolution often corresponds with that of speciation. Consequently there are many examples of karyotypes, at least in $\mathrm{C}$ banding pattern, that show some alterations between related species and/ or subspecies in mammals (A rnason, 1974 for Odontoceti; Sasaki et al., 1975 for Lemuridae; Baverstock et al., 1977 for Muridae; Deaven et al., 1977 for Peromyscus; Yosida, 1980 for Rattus spp.). So far as it is based upon the karyotype, the above conservatism of the harvest mouse does not support the specific divison of the Japanese one (M. japonicus) from the Eurasian one (M.minutus), which was proposed by Tokuda (1941).

It is well known as a biological concept that the rate of speciation or subspeciation is faster among modern forms than among ancient ones, and that it differs from species (subspecies) to species (subspecies). Schindewolf (1950) showed from the fossil records that it took one million to three million 
years for ancient forms to evolute from one genus to another one, 300 thousand to 400 thousand years for speciation, and 20 thousand to 25 thousand years for subspeciation even in the fastest case, while Moriwaki (1982) proposed a figure of one million years for subspeciation of Mus musculus, i. e. $M$. m.domesticus, M. m.molossimus, M. m. bactrianus and $M$.m. castaneus from the genetical studies.

According to the palaeographical facts, the Korean Straits began to open as a result of long lasted and prevailed erosion in the lowland areas which existed between Korea and the Tsushima Islands about 20 thousand years ago. Also, the last land bridge which had lain between the Tsushima Islands and North Kyushu was lost by a transgression ca. 16 thousand to 17 thousand years ago (Association for Geological Collaboration of Japan, 1965). On the other hand, Oshima (1980) advocated a new theory that the Korean Straits and the Tsushima Straits were formed by the so-called Shimosueyoshi transgression during the Riss-Würm interglacial period (70 thousand to 150 thousand years ago) and both the straits have been existent since then. From the facts mentioned above, we presume that the duration after formation of the two straits is not enough to cause speciation or subspeciation of Micromys .

Thus, it is concluded that the Japanese harvest mouse should be regarded as $\boldsymbol{M}$. minutus, not $M$. japonicus, and $M$. m.aokii from the Tsushima Islands, as a synonym of M.minutus japonicus from the mainland of Kyushu.

\section{ACKNOWLEDGEMENTS}

We thank the staff and graduate students of our Laboratory, Faculty of Agriculture, Kyushu University for their encouragement and help. We are also indebted to Professor F. Yasuzumi and Associate Professor, K. Andō, School of Medicine, University of Ryukyus, for their encouragement, and to Professor, E. W. Jameson, Jr., University of California for comments on the manuscript. We also wish to express deepest appreciation to Professor $\mathrm{K}$. Baba, Faculty of Education, Kumamoto University, Associate Professor K. Morimoto, Faculty of Agriculture, Kyusyu University, and Dr. K. Moriwaki, National Institute of Genetics, for their useful suggestions.

\section{REFERENCES}

Aimi, M. and $Y$. Kaneko 1971 A historical review on classifications of the Japanese cricetids and murids. Honyurui Kagaku, (22) : 19-47 (in Japanese)

Arnason, Ú.1974 Comparative chromosome studies in Cetacea.Hereditas, 77: 1-36

Association for Geological Collaboration of Japan 1985 The geologic development of the Japanese Islands. 'T'sukiji Shokan, Tokyo

Raverstock, P. R., C. H. S. Watts and J. T. Hogarth 1977 Chromosome evolution in Australian rodents I. The Pseudomyinae, the Hydromyinae and the Uromys/Melomys group. Chromosoma (Bed.), 61: 95-125

Corbet, G. B. 1973 The Mammals of the Palaearctic Region: a taxonomic review. Cornell Univ. 
Press, London and Ithaca

Deaven, L. L., L. Vidal-Rioja, J. H. Jett and T. C. Hsu 1977 Chromosomes of Peromyscus (Rodentia, Cricetidae) VI. The genomic size. Cytogenet. Cell Genet,, 19: 241-249

Imaizumi, Y. 1949 The natural history of Japanese mammals. Yōyōshobō, Tokyo (in Japanese) Imaizumi, Y. 1970 Land mammals of the Tsushima islands, Japan. Mem. Nat. Sci. Mus. Tokyo, (3) : 159-176 (in Japanese with English summary)

Imaizumi, Y. 1979 A classification of cricetids and murids of Japan. The Nature and Animals, 9(9):2-6 (in Japanese)

Imaizumi, Y., M. Kobayashi, M. Yoshiyuki and Y. Yamaguchi 1980 Small mammal fauna of Kanagawa Prefecture, Japan. Bull. Kanagawa Pref. Mus., (12): 53-68 (in Japanese with English summary)

John, B. 1976 Population Cytogenetics. Edward Arnold Ltd., London

Jüdes, U. 1981 G- and C-band karyotpes of the harvest mouse, Micromys minutus. Genetica, 54: 237-239

Kaneko, Y. 1974 On the Japanese harvest Micromys minutus from Kyoto, Chugoku, and Shikoku. Mem. Fac.Educ., Kagawa Univ., II (234): 1-9 (in Japanese with English abstract)

Král, B. 1971 Chromosome characteristics of certain murine rodents (Muridae) of the Asiatic part of the USSR. Zool. Listy, 20: 331-347

Král, B. 1972 Chromosome characteristics of Muridae and Microtidae from Czechoslovakia. Acta Sc. Nat. Brno, 6: I-78

Kuroda, N. 1922 Notes on the mammal fauna of Tsushima and Iki islands, Japan. J. Mamm., 3: 42-44

Kuroda, N. 1933 A new form of Micromys from Hondo, Japan. J. Mamm., 14: 243-244

Moriwaki, K. 1982 Genetical studies of subspeciation in Mus musculus. Zool. Mag., 91: 326 (in Japanese)

Murakami, 0. 1981 The variation and taxonomic problems of the Japanese murid rodents. Honyurui Kagaku (Mammalian Science), (42) : 59-67 (in Japanese)

Oshima, K. 1980 Recording the late-Quaternary sea-level change on the topographic feature of the straits of the Japanese Islands. Quaternary Research, 19: 23-37 (in Japanese with English summary)

Sasaki, M., M. Oshimura, E. Takahashi and N. Kondo 1975 A comparative banding analysis of chromosomes in three species of lemurs (Primates, Lemuridae). Genetica, 45: 253-261

Schindewolf, 0. H. 1950 Der Zeitfaktor in Geologie und Paläontologie. Schweizerbart, Stuttgart

Seabright, M. 1971 A rapid banding technique for human chromosomes. Lancet, II (7731): 971-972

Shiraishi, S. 1964 Size of six external characters of adult harvest mouse in Kyushu, Japan, with special reference to statistical examination of its subspecific characters. Sci. Bull. Fac. Agr., Kyushu Univ., 21: 97-109 (in Japanese with English résumé)

Sumner, A. T. 1972 A simple technique for demonstrating centromeric heterochromatin. Exptl Cell Res., 75: 304-306

Thomas, 0. 1905 The Duke of Bedford's zoological exploration in eastern Asia I. List of mammals obtained by Mr. M. P. Anderson in Japan. Proc. Zool. Soc. London, 1905 II : 331-363

Tokuda, M. 1941 A revised monograph of the Japanese and Manchou-Korean Muridae. Biogeographica, 4 : 1-155

Tsuchiya, K. 1974 Cytological and biochemical studies of Apodemus speciosus group in Japan. J. Mamm. Soc. Japan, 6: 67-87 (in Japanese with English abstract)

Tsuchiya, K. 1979 A contribution to the chromosome study in Japanese mammals. Proc Japan Acad., 55, Ser. B: 191-195 
Tsuchiya, K. 1981 On the chromosome variations in Japanese cricetid and murid rodents. Honyurui Kagaku (Mammalian Science), (42) : 51--58 (in Japanese)

Tsuchiya, K. and T.H. Yosida 1971 Chromosome survey of small mammals in Japan. Ann. Rep. Nat, Inst. Gen. Japan, (21): 54-55

Yosida, T. H. 1980 Cytogenetics of the Black Rut. University of Tokyo Press, Tokyo 